\title{
The Right to Know? The Politics of Information about Contraception in France (1950s-80s)
}

\author{
BIBIA PAVARD * \\ Associate Professor, University Paris 2-Panthéon Assas, Researcher at CARISM (Center for \\ Interdisciplinary Analysis and Research on the Media), 5/7 avenue Vavin 75006 Paris
}

\begin{abstract}
In 1920 in France, a law was passed prohibiting abortion, the sale of contraceptives and 'anti-conception propaganda'. While contraception was legalised in 1967 and abortion in 1975, 'anti-natalist propaganda' remained forbidden. This article takes seriously the aim of the French state to prevent the circulation of information for demographic reasons. Drawing from government archives, social movement archives and media coverage, the article focuses on the way the propaganda ban contributed to shaping the public debate on contraception as well as lastingly impacting the ability of the state to communicate on the subject. It first shows how birth control activists challenged the legal interdiction against communicating about contraception (1956-67) without questioning the natalist obligation. It then shows how, after 1968, communication on contraception became a power struggle carried out by various actors (sexologists and feminist and leftist activists) and how the dissemination of information about contraception was thought of as a way to challenge moral and social values. Finally, the article describes the change of state communication policies in the mid-1970s, leading to the first national campaign on contraception launched in 1981, which defined information as a task that women should take on.
\end{abstract}

Keywords: France, Contraception, Information, State campaign

The politics of information from the 1950 s to the 1980 s is a revealing point of entry for studying contraception in France. The period is characterised by a major shift: the legalisation of contraception (1967) and abortion (1975) after a long-term interdiction against these practices on the grounds of fear of population decrease. While the history of the liberalisation of contraception and abortion in France has been covered by several studies, ${ }^{1}$ the focus on information enables a better understanding of such a shift and adds to the complexity of the 'sexual revolution'.

\footnotetext{
* Email address for correspondence: bibia.pavard@u-paris2.fr I would like to thank Caroline Rusterholz and Jesse Olszynko-Gryn for building a stimulating international network of researchers and for the brio with which they supervised the special issue.

${ }^{1}$ Janine Mossuz-Lavau, Les lois de l'amour, les politiques de la sexualité en France de 1950 à nos jours [The Laws of Love, Sexual Politics in France from 1950 to the Present] (Paris: Payot, 2002); Bibia Pavard Si je veux, quand je veux. Contraception et avortement dans la société française 1956-79 [If I Want It, When I Want It. Contraception and Abortion in French Society 1956-79] (Rennes: Presses universitaires de Rennes, 2012).
} 
Information about birth control was initially made illegal in France after the First World War, by the 1920 law forbidding the inducing of abortion, the sale of contraceptives and the spread of 'anti-conception propaganda'. The text prohibited the circulation of any kind of book, writing, print, poster, drawing, image or advertisement 'describing or offering to reveal' methods preventing pregnancy. The French situation from the 1920s to the 1960s was, then, very different from contexts such as Britain, where information on contraceptive methods for married couples was spread freely by birth control organisations, the mass media and bestselling books. ${ }^{2}$ The French legislation implied a specific construction of common knowledge of contraceptives and impacted the politics of information and communication about contraception. Outlawing propaganda shaped the public discourse on birth control. It also placed information at the centre of collective actions: various actors contested the interdiction and contributed to defining a legitimate - if not legal - widespread dissemination of information about contraception. First, from the creation of the first French birth control association in 1956 to the legalisation of contraception in 1967, information was gradually framed as a way to limit backstreet abortions and guarantee the happiness of families, as new contraception experts managed to separate information from anti-natalist propaganda. After ten years of lobbying, a new law in 1967 enabled the production and sale of contraceptives. From 1968 to 1975, demands for wider dissemination of information about contraception were put forward by various actors (physicians and birth control and feminist activists), who also produced and circulated different types of material describing contraceptive methods. The right to access information was put on a revolutionary agenda, as feminists developed the idea that knowing one's body was a way to reclaim it. After various activists demanded free contraception and abortion, the 1974 legislation made it legal to sell contraception to minors without parental authorisation and enabled contraceptives to be covered by the national healthcare system. However, 'anti-natalist propaganda' remained forbidden: the legal interdiction against public discourse contesting the necessity of a growing population lingered. Those who changed the law were very careful to make contraception possible without encouraging it. Ignorance was still considered an instrument for population control and a way to avoid a demographic crash. As a result, the first national public campaign was not launched until fourteen years after the legalisation of contraception, in 1981, by the Minister of Women's Rights. The message of the campaign was that information about contraception was not only a right but a duty, though it carefully avoided encouraging contraception itself. Information was, then, portrayed as an individual effort that women should make. Drawing from activist and state archives, this article argues that freedom of contraception was limited in France by the enduring interdiction against propaganda.

\section{Is Propaganda More Dangerous than Ignorance? The Challenge of the Legal Interdiction by New Contraception Experts (1956-67)}

The 1920 law succeeded where several attempts to condemn the circulation of brochures exposing birth control methods by Neo-Malthusian activists had failed. After the 1870 defeat by the Prussians, fin de siècle France had been the theatre of an intense battle between anti-abortion activists on a moral crusade against public indecency

\footnotetext{
${ }^{2}$ For a comparative perspective on the circulation of information about reproduction see the Bulletin of History of Medicine, 'Communicating Reproduction', 89 (2015) and Kate Fisher, Birth Control, Sex and Marriage in Britain, 1918-60 (Oxford: Oxford University Press, 2006).
} 
and 'depopulation' 3 and the socialists, anarchists and feminists who promoted sexual education and reproductive freedom for the working class. ${ }^{4}$ In the post-Great War context of demographic crisis, the 1920 law was designed to combat charlatanism, silence the Neo-Malthusian activists and ensure population growth: it definitively forbade the dissemination of information concerning contraception.

In 1956, after three decades of repressed birth control activism, Marie-Andrée Lagroua Weill-Hallé, a gynaecologist willing to challenge the 1920 legislation on contraception, created a new association. Joined by upper-class educated women (lawyers, writers, doctors, housewives), all 'honourable mothers', it contributed to making family planning respectable in France. Because the 1920 law prohibited propaganda supporting birth control, Marie-Andrée Lagroua Weill-Hallé and her colleagues had to work very carefully in order to avoid crossing a fine line that would put them in an illegal position. ${ }^{5}$ Their first move was to call the association Happy Motherhood and to present birth control as a way to better family life in accord with familialism: 'an ideology grounded on the defence of the family as an institution', at the centre of public action in France, conveying a 'conservative view of the whole social order, with the family as its basis, headed by a male breadwinner' ${ }^{6}$ They also worked to define information about birth control as a legitimate and legal practice. These new French planned-parenthood advocates argued that ignorance about contraception was more dangerous than propaganda, since ignorance led to unwanted pregnancies and backstreet abortions, negatively affecting the reproductive health of women and potentially causing death. Several articles in the liberal newspapers (Libération, France Observateur and L'Express) in 1956 backed their position, drawing from the testimony of ordinary people and opening a public debate on the subject. Indeed, making the voice of ordinary women heard became a way to assert the existence of a social problem. Marie-Andrée Lagroua Weill-Hallé explained that her 'conversion' to family planning had been influenced by encounters with many unhappy women and couples in her gynaecology practice. In 1960, she published a book titled La grand'peur d'aimer ('The Great Fear of Loving'), collecting various tragic cases she had come across that could have been avoided with efficient contraception. The philosopher Simone de Beauvoir, who had already invoked the role of contraception to emancipate women in her 1949 book The Second Sex, prefaced it. ${ }^{7}$

\footnotetext{
${ }^{3}$ Fabrice Cahen, Gouverner les mœurs. La lutte contre l'avortement en France, 1890-1950 [Governing Vice. The Struggle against Abortion in France] (Paris: INED Editions, 2016).

${ }^{4}$ Elinor Accampo 'The Gendered Nature of Contraception in France: Neo-Malthusianism, 1900-20', Journal of Interdisciplinary History, 34 (2003), 235-62 and Anne Cova, Féminisme et néo-malthusianisme sous la III e République «La liberté de la maternité» [Feminism and Néo-Mathusianism during the Third Republic: 'The Free Maternity'] (Paris: L'Harmattan, 2011).

${ }^{5}$ Francis Sanseigne, 'Le Planning Familial face à la loi (1956-67): entre arrangement et transformation' [French Family Planning and Law (1956-67): Between Compromise and Transformation], Nouvelles questions féministes, 29 (2010), 16-31.

${ }^{6}$ Anne Revillard, 'Stating Family Values and Women's Rights: Familialism and Feminism within the French Republic', French Politics, 5 (2007), 210-28, 211.

7 Bibia Pavard, 'Une "guerre de 20 ans": les luttes du planning familial dans L'Express et Le Nouvel Observateur (1955-75)' [A 20-year war: the family planning battle in L'Express and Le Nouvel Observateur], in Christine Bard and Janine Mossuz-Lavau (eds), Le planning familial. Histoire et mémoire [Family Planning. History and Memory] (Rennes: Presses universitaires de Rennes, 2006), 119-26.
} 


\section{Establishing Contraception Experts}

Aside from making the experience of ordinary couples heard, legitimising information about contraception also implied establishing new birth control experts. Lay knowledge was rejected as inefficient, while 'modern contraceptives' (namely those that needed technical knowledge for use, such as diaphragms combined with spermicide) were praised. From its very creation, Happy Motherhood defined its action as scientific. Its goals were described in the statutes of the association as 'the study of the problems of motherhood, birth, of their familial, social and national repercussions' and 'the research of scientific information in France and abroad concerning these problems'. The scientific goals were twofold: using tools developed by social sciences to study the question of birth control on the one hand, and using hard-science research on contraceptive techniques on the other. The aim was to prove scientifically that contraception would better people's lives and that the French population was ready for it. Psychiatrists and sociologists presented their work in the newsletter of the association. Association members, gynaecologists and lawyers published books on contraception. Surveys and inquiries were initiated to test the opinion of French citizens on birth control.

Comparison with other countries was also used as an incentive to 'modernise' France. Happy Motherhood members established relations with foreign birth control activists and the International Planned Parenthood Federation (IPPF). In 1959, after the association became part of the IPPF, Marie-Andrée Lagroua Weill-Hallé published a book entirely based on its documentation to present the use of birth control in different countries. ${ }^{8}$ Moreover, French birth control activists were educated by IPPF activists through the Family Planning Association in London, and regularly travelled to England or to large IPPF conferences around the world. The construction of French birth control knowledge was partly the result of an advocacy transfer; ${ }^{9}$ French activists translated and adapted pre-existing information to the French situation, making sure that birth control was not associated with a population drop, considering the strong concerns about 'depopulation' in metropolitan France.

In 1960, Happy Motherhood became the French Family Planning Movement; the word 'family' was chosen to confirm that its aim was not to limit population. The next year, the first 'family planning centre' was opened in the city of Grenoble (more followed rapidly) to provide counselling to couples on sexuality and well-being. In fact, people could come to these centres for instruction on how to attain contraceptives. It was a real turning point for the association. Because contraceptives were illegal, the procedure was very complex. It had three stages: first, one had to go to a centre, meet counsellors and join the association (so the information could not be considered as propaganda but instead as an internal matter); next, she (or more rarely he) was directed to an affiliated doctor who prescribed contraceptives; and, finally, the prescription was sent to England or Switzerland through the family planning centre and contraceptives sent by mail. This process gave a crucial role to doctors, since they were the ones who wrote the prescriptions. Moreover, these doctors were usually the directors of the individual family planning centres. Counsellors played an important role too, welcoming women and couples and providing reassuring advice in situations that were sometimes painful; however, in the association, they

\footnotetext{
${ }^{8}$ Marie-Andrée Weill-Hallé, Le «Planning» familial (Paris: Maloine, 1959).

9 'Du Birth Control au Planning Familial (1955-60): un transfert militant?' [From Birth Control to Family Planning in France (1956-60): An Advocacy Transfer], Histoire@ Politique. Politique, culture, société, 18 (2012), https://www.cairn.info/revue-histoire-politique-2012-3-page-162.htm.
} 
remained in a subordinate position. Simone Iff, who was a counsellor in the 1960s and became president of the association in 1973, spoke about the lack of consideration the counsellors experienced, recounting that, for example, they were not allowed to write for the newsletter; neither were they invited to take part in the decisions concerning the association. As a substantial number of men, especially physicians, entered the association at the beginning of the 1960s (the physicians were not solely men - a high proportion of women doctors were involved in the association compared with the total number of women physicians in France), and as all the counsellors were women, a gendered hierarchy was created, with the caring aspect of the family planning centres subordinate to the medical aspect. The physicians asserted their role as the only intermediaries available to obtain contraceptive devices, and they had a great influence on the position of the association through its Medical Council, created in 1962 and headed by the gynaecologist Pierre Simon. Moreover, in the 1960s, the pill became central in the debate about birth control, altering it considerably by changing the perspective to a medical one: was the pill safe? Physicians in the association conveyed a certain image of seriousness and professionalism, which made it even easier to circulate information about contraception in books or through interviews in newspapers and on television to provide reassurance about the pill. Family planning centres became information centres and were not accused of 'anti-conception propaganda'. In this way, they created a precedent, which became hard for the state to ignore. ${ }^{10}$

\section{The Legalisation of Contraception: What Could the State Let Happen?}

In 1965, after almost ten years of lobbying for contraception by the French Family Planning Movement, the issue entered the political agenda when François Mitterrand, the left-wing candidate, declared during the presidential campaign that he would legalise contraception if he were elected. Almost all candidates made declarations on the subject after this, and the government could not avoid the issue anymore. Charles De Gaulle was re-elected and, because of his conservative views on family, did not support legislative change regarding birth control. However, his administration had already commissioned two reports on the possible impact of the liberalisation of birth control: the first focused on the medical aspects of the pill, concluding there was no danger, and the second focused on the demographic issues raised by birth control. The latter was produced by the National Institute of Demographic Studies (INED), a public agency created in 1945 whose demographers - such as Alfred Sauvy, who headed it until 1962 - opposed demographic arguments to the liberalisation of contraception during the 1950s. However, the 1966 INED report adopted a pragmatic answer to the question asked by the Minister of Social Affairs: 'What would be the effect on the birth rate of the adoption of a more liberal policy on birth control?' The report expected a 5\%-10\% birth-rate drop due to more efficient contraceptive methods (the pill and the intrauterine device (IUD)) and a rise of $0.9 \%$ in the healthcare budget if contraceptives were to be covered. However, family allowances could be increased in order to counter the birth-rate drop. Moreover, the report recommended compensating for the potential liberalisation by implementing an information campaign

\footnotetext{
${ }^{10}$ The analysis of the gender organization of the French Family Planning Movement in the 1960s draws from the archives of the association (D0401-D0405; D0804) and seven interviews with former members as well as testimonies published in Bard and Mossuz-Lavau (eds), op. cit. (note 7) and Collectif, D'une Révolte à une lutte: 25 ans d'histoire du Planning Familial [From Rebellion to Struggle: 25 Years of Family Planning] (Paris: Tierce, 1982).
} 
arguing against the idea that there were too many children in France and not enough housing or jobs. The report insisted on collective psychology: 'In a country like France, where birth control is intensely applied, the number of children does not only rely on individual attitudes and calculations. Or, if one prefers, these calculations and attitudes are inspired, in part, by the collective atmosphere' (p. 677). The various studies produced in 1966 and 1967 all acknowledged the need for the state to reconsider its demographic policy, promoting the idea that 'in industrialised countries the level of individualisation is such that it is necessary to look into intimate decisions to analyse birth-rate fluctuations'. ${ }^{11}$

However, despite the different reports all converging on the idea of necessary change, the decision to amend the legislation was not taken by the government. A Member of Parliament (MP), Lucien Neuwirth, who played a decisive intermediary role between the government and the French Family Planning Movement, took the initiative. Contraception reform aroused great debate in Parliament. ${ }^{12}$ One conservative MP, Jean Coumaros (National Assembly, second session, 1 July 1967), regarded the debate itself as dangerous: 'But ourselves, my dear colleagues, aren't we producing unbridled propaganda, better than any advertisement company could do? It is unfortunate that such a project cannot be discussed behind closed doors, just like indecency cases in criminal court. ${ }^{13}$ Publicly discussing the subject was considered a step too far for certain politicians. Other MPs insisted on the danger that women could use contraceptives without the knowledge of their husbands, revealing the gendered construction of information: it seemed unacceptable for women to know more about sex than men. However, in spite of the moral arguments from conservatives (contraception going against God's will and stirring up the risk of ethical corruption; the pill being counter-nature) and a demographic scare, a centreleft majority was formed in order to pass the new legislation. The main arguments put forward in support of free contraception were pragmatic (reducing backstreet abortions, acknowledging a wide public demand for change and reducing France's scientific lag) and ethical (promoting freedom of choice and equality between upper- and lower-class couples). However, to form the parliamentary majority, concessions had to be made, and though many left-wing MPs insisted on the necessity of promoting sexual education and information, the final version of the law reaffirmed the ban on anti-conception propaganda and advertisements for contraceptives (except in medical journals). Combined with the fact that contraceptives were not covered by social security and that minors needed parental consent, the law was designed to avoid encouraging contraception. Information continued to be seen as a tool for population control.

This was also evident in the special, and contrary, treatment reserved by the law for the French Caribbean and Reunion island (DOM), where extensive contraception propaganda had been employed since the beginning of the 1960s, as the population was

\footnotetext{
11 Paul-André Rosental, L'intelligence démographique. Sciences et politiques des populations en France, 1930 60 [Demographic Intelligence. Population Sciences and Policies in France, 1930-60] (Paris: Odile Jacob, 2003), 236 (personal translation).

12 The analysis of the debate in Parliament is based on Journal officiel de la République française and an interview with Lucien Neuwirth (4 April 2006); see also Mossuz-Lavau, op. cit. (note 1).

13 'Mais nous-mêmes, mes chers collègues, ne faisons-nous pas une propagande effrénée et sans pudeur, mieux que ne saurait le faire la meilleure maison de publicité ? Il est regrettable qu'un tel projet ne puisse être discuté à huis clos, comme aux assises quand il s'agit d'affaires de mœurs', Jean Coumaros, Journal Officiel de la République française, Assemblée nationale, 1 July 1967, 2569.
} 
thought to be expanding too quickly. ${ }^{14}$ In metropolitan France, however, information about contraception was thought to be a private matter linked to family counselling. The law established two types of expertise: family counselling by 'information, consultation or family counsel centres' (which now needed approval from the state) and medical information about and prescription of contraceptives. However, after the 1968 events in France, information about contraception was redefined by feminist and leftist activists.

\section{Learn About Yourself! Information, Gender and Power (1968-75)}

During the 1970s, equal access to knowledge about contraception became a hotly debated issue, and different actors contributed to a general promotion of birth control. Two main trends emerged after the liberalisation of contraception in 1967: new 'sexperts' became visible in the mass media, while, with the 1968 events, sexual matters became part of a revolutionary project to demolish bourgeois family values and capitalist society. The rise of the feminist movement at the turn of the 1970s changed the framing of contraception and abortion issues into a question of women's liberation. This change linked contraception to individual emancipation and made information about contraception a 'women's issue'.

\section{The Rise of a New Sexology as a Source of Knowledge about Contraception}

After the 1967 legislation, the French Family Planning Movement echoed the new ethics for heterosexual married couples promoted by sexologists. ${ }^{15}$ Though the work of Alfred Kinsey in the 1950s had not met the same success in France as in the United States, the work of William Masters and Virginia Johnson, published in 1966 and based on a clinical study, enjoyed wider media coverage. The French Family Planning Movement played an important role in popularising their positive views on sexuality, not only in the newsletter of the movement and through the publication of books but also by speaking as experts in the media, especially women's magazines and television. The television news show Zoom, dedicated to sexual education on 13 February 1968, is a typical example: on the set, four experts were invited to comment on various subjects (a single mother, a conversation between a gynaecologist and a teenager, high-school teachers and a mother answering her six-year-old son's questions about sex). The four experts were all members of the medical college of the French Family Planning Movement. They seized the opportunity to promote sexual education for young people.

More generally, in the media, discourse about sex was the preserve of scientific experts, doctors in particular. Globally, these new 'sexperts' promoted guiltless pleasure. In the Family Planning Bulletin in March 1969, gynaecologist Suzanne Képès and sociologist Catherine Valabrègue wondered, 'Is pleasure immoral when it is shared? Is pleasure a source of hatred or love for your neighbour? Is pleasure the generator of war or peace?' Similarly, some members of the family planning community supported the right of young people to a free sexuality after the May and June 1968 events. Catherine Valabrègue published a book on 'student life' in 1970: in a chapter called 'sexual revolution', she observed that 'young people have naturally inserted the fight against sexual taboos in their

${ }^{14}$ Arlette Gautier, 'Les politiques familiales et démographiques dans les départements français d'Outre-mer depuis 1946' [Family and Demographic Policies in the French Overseas Departments since 1946], Cahiers des sciences humaines, 24 (1988), 389-402; Françoise Vergès, Le ventre des femmes. Capitalisme, racialisation, féminisme [Women's Womb. Capitalism, Race and Feminism] (Paris: Albin Michel, 2017).

15 Sylvie Chaperon, 'Kinsey: les sexualités féminines et masculines en débat' [Kinsey: Debating Feminine and Masculine Sexualities], Le Mouvement Social, 198 (2002), 97. 
demand for freedom' and that it was not a search for 'immediate satisfaction and at any price of their sexual impulses' but instead 'looking for new sexual ethics'. ${ }^{16}$

However, liberalisation of speech did not reflect a radical change in contraceptive practices. The work of Anne-Claire Rebreyend, who studied intimacy in France between the 1920s and 1970s through autobiographical papers (diaries, correspondence), shows inertia in contraceptive practices. ${ }^{17}$ The first major sex survey that provided information on both sexual practices themselves and the new ambition in France to study them confirmed this tendency. The 'Report on the Sexual Behaviour of the French' was launched in 1969, using a representative sample of the national population aged 20 and above. It was led by the gynaecologist Pierre Simon, a former family planning activist who was now working for the Ministry of Health, alongside Anne-Marie Dourlen-Rollier, a lawyer, pioneer of the French Family Planning Movement and author of several books on contraception and abortion, and Jean Gondonneau, a member of the Rouen section who was preparing a sociology thesis on sexuality. ${ }^{18}$ The survey showed that the most frequently used method for birth control remained withdrawal, followed by the temperature method (periodic abstinence), while the pill was only used by $18 \%$ of women of reproductive age. Diaphragms, caps and spermicides, which were recommended by the IPPF in the 1960 s, were only used by $4 \%$ of the population in 1970, and were therefore very marginal methods. The IUD was little known and used by a small fraction of the population. It must still be noted that the contraceptive practices of the French were beginning to change - a replacement of old practices with 'modern practices' - which Henri Léridon called 'the second contraceptive revolution'. ${ }^{19}$ Social background, religious practice and generation, however, conditioned the transition from traditional to new methods. Though this was true for the use of any contraceptive method, it was even truer for oral contraceptives. 'The spread of the pill began with the youngest segment of the population, the most urbanised, the most educated, and finally those of the most advantaged backgrounds. It then reached all social circles, all ages, classes and regions,' Henry Leridon wrote. Studies on the use of contraceptive methods also show that in the early 1970s there was a wide gap between the knowledge of the existence of contraceptive methods and their effective use. Thus, $94 \%$ of respondents had heard of the pill, but only $10 \%$ had used it to avoid pregnancy.

Contemporary experts saw the discrepancy between awareness of contraceptives and poor use of them as a sign of social and cultural inertia. Some considered that women had difficulty accepting their libido because 'many women still considered physical relationships as a sin', while men resisted the sexual freedom of their wives and feared adultery. ${ }^{20}$ Moreover, some women feared the side effects of the pill. This new data on contraceptive behaviours was used to support demands for more information and sexual education. It also served to attack the 1967 legislation, which was considered too limited, especially for minors (under 21), who were required to obtain parental authorisation in

\footnotetext{
16 Catherine Valabrègue, La Condition étudiante [The Student Condition] (Paris: Payot, 1970), 8, 39.

17 Anne-Claire Rebreyend, Intimités amoureuses, France (1920-75) [Intimate Love, France (1920-75)] (Toulouse: Presses du Mirail, 2008), 314.

${ }^{18}$ Pierre Simon, Jean Gondonneau, Lucien Mironer and Anne-Marie Dourlen-Rollier, Rapport sur le comportement sexuel des Français (Paris: René Julliard et Pierre Charron, 1972)

${ }^{19}$ Henri Leridon, 'La Seconde révolution contraceptive: la régulation des naissances en France, 1950-85' [The Second Contraceptive Revolution: Birth Control in France, 1950-85], Population, 42, 2 (1985), 359-67.

20 "'Pills that fail": interview with "an eminent gynecologist" whose name is not given ...', Marie Claire (October 1971), 230.
} 
order to purchase the pill. The emerging feminist movement in that context, added a new demand: women's ownership of their bodies.

\section{Knowledge Is Power: Revolutionary Readings of Information}

The Women's Liberation Movement brought about a new definition of information about contraception. Emerging in France after 1968, and becoming visible in 1970 due to several public actions, the feminist movement, just like in other countries, asserted that knowledge about contraception was a critical issue for women. Learning about one's anatomy and the reproductive cycle was conceived as part of a more general revolutionary agenda. In various feminist documents - journals, leaflets and books - the taboo on sexuality was presented as a tool to keep women in ignorance and perpetuate male domination. Hence, free contraception and abortion, as well as knowledge about birth control, were seen as tools to overcome patriarchy: 'Women who gave themselves the possibility to choose contraception are those who have escaped the role that society wants to assign them and who have escaped the morals of that society spread by priests, doctors, fathers and husbands,' one anonymous article, titled 'Contraception', explained in the first edition of the Mouvement de libération des femmes's newspaper, the Torchon Brûle, in 1971. ${ }^{21}$ Different readings of the issue of contraception and abortion, in line with different political views, were presented in Women's Liberation Movement publications; however, knowing about one's own sexuality was always seen as a way to contest gender roles, since, as Kate Fischer has shown for the English context, women were not supposed to know about sexual matters before marriage. ${ }^{22}$ Information about contraception was included in a more general agenda to emancipate women from imposed moral constraints. Some writings focused on the more complex relations that women had with contraception and abortion - for example, questioning the evidence of the use of contraceptives. One collective document written by 'mothers, non-mothers, married women, single women, homosexuals, some having had an abortion, others not, and everyone but one having used or using contraceptives' specifically expressed ambivalence: 'We are thus caught in a contradiction: we recognise the necessity of contraception and at the same time we live it as an attack, an aggression, a rape, as an alienation. ${ }^{23}$ Despite this critical vision of contraception, the aim of liberating women's bodies remained.

The Women's Liberation Movement also contested the idea that there should be sexual 'experts', especially doctors, since every woman had the right to become the expert on her own body. Activists knew that knowledge was power and worked to give this power back to lay women. This is why they produced alternative information, in accessible language and with many illustrations. Several brochures were printed and distributed locally. They showed freehand drawings of reproductive organs, explained ovulation and detailed different contraceptive methods. In the second half of the 1970s, French feminist groups tried to impose a gynaecological counter-expertise in the context of the transnational circulation of self-help practices. For example, in 1977, the French translation of the book Our Bodies, Ourselves became available; it had first been published by the Boston Women's Health Book Collective in 1971, which presented the variety of available contraceptive methods very thoroughly. However, according to Ilana Löwy, these

21 Anonymous, 'Contraception', Le Torchon Brûle, 1 (1971), no date, no page.

${ }^{22}$ Kate Fisher shows in her study about Great Britain that 'being innocent was presented as a crucial aspect of female identity, particularly among the working classes': textitop. cit. (note 2), 66.

${ }^{23}$ Anonymous, supplement of Torchon Brûle, 5 (1973), no date, no page. 
self-help movements remained very limited in France compared to the United States, due to an efficient healthcare system, the very specific spread of medical gynaecology and the weak investment of feminists in bio-medicine research. ${ }^{24}$ Feminist groups did not offer much information on alternative contraception practices. Moreover, feminist documentation did not question the information disseminated by the medical field and did not, for example, question the use of the pill, in contrast with feminist groups in the United States. ${ }^{25}$ Rather, feminist production was meant to help women access existing information and to alert them to its political implications.

Besides feminist groups, other leftist collectives circulated leaflets on contraception and abortion, such as the Movement for the Liberation of Abortion and Contraception (MLAC), created by doctors, trade unionists and left-wing - especially Maoists and Trotskyists - and feminist activists in 1973. The collective helped women to access illegal abortions in France, performed by members of the group with the vacuum aspiration method, or in nearby countries (Holland, Switzerland or England), organising abortion travel. In its founding 'Charter' (1973), the MLAC demanded sexual information, freedom of abortion and contraception, including 'the development of wider information on the problems of contraception and procreation through campaigns to popularise contraceptive methods and the demystification of false propaganda'. Information about contraception was part of a global agenda to redefine sexuality and to contest the power relations between doctors and patients. Informed patients were thought to be more conscious and capable of interacting more equally with physicians. As the Charter stated:

The MLAC will strive for people to take charge of all these problems by organising themselves at all levels (neighbourhoods, businesses, schools, etc.). In particular, in order for people to impose the creation of centres that will make sexual information, contraception and abortion available to all, under the best conditions, and their popularisation. These centres will be meeting places that will allow women to break their isolation due to guilt around abortion and due to the lack of information. ${ }^{26}$

As a consequence of the mobilisation of feminists and the MLAC, a dramatic change occurred in the French Family Planning Movement in 1973. The general assembly brought to power Simone Iff - for the first time, a counsellor and not a doctor - who had contributed to the foundation of the MLAC, was in favour of the liberalisation of abortion and had a programme of alliance with the feminist movement. Subsequently, the national and local family planning associations took part in the circulation of alternative information about contraception and abortion, as well as helping women to access abortions. The French Family Planning Movement also played an important role by collecting data nationwide about contraceptive and abortion practices. The medical council dissolved itself; former members who disagreed with the new strategy left the movement and created a new association, the Institute for Training, Research and Studies on Sexuality and Family Planning (IFRES). They promoted medical information in their journal

\footnotetext{
${ }^{24}$ See Ilana Löwy, 'Le féminisme a-t-il changé la recherche biomédicale? Le Women's Health Movement et les transformations de la médecine aux États-Unis' [Has Feminism Modified Biomedical Research? The Women's Health Movement and Changes in Medicine in the US], Travail, genre et sociétés, 14 (2005), 103 and Lucile Ruault, 'La circulation transnationale du self-help féministe: acte 2 des luttes pour l'avortement libre ?' [The Transnational Circulation of Feminist Self-Help: The Second Act in the Fight for Abortion Rights?], Critique internationale, 70 (2016), 37-54.

${ }^{25}$ Elizabeth Watkins, On the Pill: A Social History of Oral Contraceptives, 1950-70 (Baltimore, MD: Johns Hopkins University Press, 1998).

${ }^{26}$ MLAC Charter, Bibliothèque Marguerite Durand, DOS MLAC.
} 
(Contraception, Fertility, Sexuality) and in brochures, claiming a position of neutral expertise based on scientific studies.

A comparison of the different brochures produced during the first half of the 1970s reveals variations in the promotion of contraception according to political position. The MLAC, for example, promoted non-reversible methods (vasectomy and tubal ligation), while the IFRES did not. These political tensions around information had an impact on state policies, especially after the legalisation of abortion in 1975. While the period 196775 was characterised by polyphony of discourse on contraception, the government studied the possibility of disseminating information designed to become the official word on it.

\section{Changing Policies: The Redefinition of Information as a Personal Goal} (1975-82)

From 1971 to 1975, abortion was an important issue in France. Feminists demanded free abortion and leftist organisations started performing illegal terminations, while reformist organisations pushed for legislative change, finally resulting in legislation reform entering the political agenda. In 1973, President Georges Pompidou's death brought to power Valéry Giscard d'Estaing, a centrist politician whose aim was to 'modernise' France. Abortion reform took place in this political context. The issue of abortion highlighted the critical role of contraception, since many argued that the use of efficient contraceptives could prevent unwanted pregnancies. Before discussing a new law on abortion in Parliament, ${ }^{27}$ the Minister of Health, Simone Veil, proposed a very liberal law on contraception, which was adopted in December 1974, passing easily compared with the strong resistance met by the first reform in 1967. It made contraception accessible to minors, and 'modern contraceptives' (the pill, the IUD) were now covered by social security. It was meant to 'normalise' contraception, as the minister put it. However the ban on propaganda remained, since the new law specified that 'all anti-natalist propaganda [was] prohibited'. Any 'commercial advertising of contraceptives [was] prohibited except in publications dedicated to doctors and pharmacists'. This permanence shows that natalism remained the frame for public action on contraception. The 1975 law on 'voluntary termination of pregnancy' was also very restrictive: it presented itself as tolerance for women 'in distress', but they had to go through a preliminary interview, while the medical act was not covered by social security. The interdiction against propaganda and publicity impacted mass-information possibilities. How could organisations inform the public about contraception without inciting its use? New initiatives by the Ministry of Health resulted in a focus on individual behaviours.

\section{Defining Official Information (1975-81)}

In 1976, the Ministry of Health backed the creation of an information centre on birth control, motherhood and sexual life (Centre d'Information sur la Régulation des naissances, la maternité et la vie sexuelle). It took the form of a private association financed by public funding and was directed by civil servants. Its main actions were to produce an information brochure distributed in social centres and pharmacies and to open a telephone line. This is a good example of the state's new definition of information about contraception in a liberal context. First of all, birth control was included in the more global

${ }^{27}$ On the abortion reform see Pavard, op. cit. (note 1). 
approach of public policies concerning parenthood. As a result, the brochure produced by the information centre was presented as a way to learn about 'effective contraception' but also about 'preparing for pregnancy and a happy childbirth', 'possible sterility', 'the adoption of a child', 'venereal diseases' and 'abortion'. Moreover, the brochure was conceived as a way to stress good practices and denounce bad practices. The section about abortion is typical:

Abortion is possible in France since the January 171975 law. It is a serious act that a pregnant woman in a distress situation may ask a doctor to practice - and only a doctor [highlighted in blue] [...] Abortion should not be a means of birth control because its repetition creates risks for the woman and the future child [this last part is written in larger font and in blue].

This example shows how the information not only aimed to help readers make a decision but also to orientate it towards contraception rather than abortion, which was clearly demonised. The brochure also stressed the role of doctors, while the new law strictly forbade lay practices, in order to eliminate militant abortion practice. There were indeed a few feminist groups that continued to perform abortions outside the hospital after 1975, risking a trial, such as the one condemning Aix-en-Provence MLAC activists in 1977 for illegal practice of medicine. ${ }^{28}$ The telephone line was a traditional policy instrument for the state to communicate with citizens. An internal survey conducted during the month of May 1976 showed that the majority of calls (25\%, mainly women) were made to ask about birth control; after this came questions about sexual problems (20\%, mainly men). This proves the need for information and the absence of a specific public action for it. ${ }^{29}$

While the state established this timid information policy, birth control activists continued to spread knowledge. Doctors, gynaecologists in particular, played a major role as an information resource, and the French Family Planning Movement pursued its work. Feminist activists also circulated their own vision on the subject, more critical of medical power. Public archives show a power struggle over who should define official information about contraception. An association dedicated to information about contraception was created in 1977, for the anniversary of the 1967 contraception law, by two prestigious birth control champions, Marie-Andrée Lagroua Weill-Hallé (the founder and former president of the French Family Planning Movement) and Lucien Neuwirth (the politician who defended the legalisation of contraception in Parliament in 1967). Named the National Committee for Birth Control, its purpose was clearly formulated: 'to raise awareness on birth control, to inform about ways to learn about it, to propose the necessary legislative and regulatory changes on the subject'. One of its goals was 'to amend [the] subsection of the law that prohibits any propaganda for contraception and explore the most effective means of communication to create in all French couples the motivation that will make them seek information about birth control with specialised organisations ${ }^{\prime 30}$. This National Committee for Birth Control lobbied the Ministry of Health in order to establish its own expertise but did not succeed in convincing state actors to organise a vast campaign. During a public meeting in 1977, the head of the association, addressing a member of the Ministry

\footnotetext{
${ }^{28}$ Lucile Ruault, 'Le spéculum, la canule et le miroir. Les MLAC et mobilisations de santé des femmes, entre appropriation féministe et propriété médicale de l'avortement (France, 1972-84). [Speculum, Cannula and Mirror. The MLACs and Women's Health Mobilizations, between Feminist Appropriation and Medical Property of Abortion (France, 1972-84)] (unpublished PhD thesis: University of Lille, 2017).

${ }^{29}$ French National Archives, Direction générale de la Santé, 19850019, art. 18, Centre d'information sur le contrôle des naissances, la maternité et la vie sexuelle (Information Centre on Birth Control, Motherhood and Sexual Life.

${ }^{30}$ French National Archives, Direction générale de la Santé, 19850019, art. 19, press release, 10 February 1976.
} 
of Health who was present, defined the position of the Committee as an intermediary between the 'unconditional defenders of life' and the 'feminist-extremists', against the IPPF's promotion of sterilisation. ${ }^{31}$ In other words, the Committee was working to prove its compatibility with the natalist imperative; in a letter addressed to the Minister of Health in 1980, its heads presented it as the only entity capable of promoting information 'in a disinterested spirit' and 'without making it a means for fighting public authorities' ${ }^{32}$

All of this shows that during the 1970s information about contraception was a debated issue. Different actors presented various views on what form it should take and what its purpose should be (limitation of abortions, women's control over their own bodies, sexual well-being in married couples). It was with the political majority shift in 1981 that the first public campaign was launched, setting a precedent for the nature of state information about contraception.

\section{The 1981-2 Campaign: Information about Contraception, a Woman's Right. ... and Duty}

In 1981, François Mitterrand, the first socialist president of the Fifth Republic, was elected. He nominated Yvette Roudy as his government's Minister of Women's Rights. A feminist herself and close to the feminist movement, Roudy held contraception and abortion rights to be one of her priorities. She hired former president of the French Family Planning Movement Simone Iff as a counsellor on the issues of sexuality, rape, violence and prostitution, another statement of her commitment to those themes and a signal of her political approach. ${ }^{33}$

In 1982, Roudy ensured that abortions were covered by social security. Before that, in 1981, she launched the first national campaign on contraception. She made the choice to use a professional communication agency to build a large-scale plan of diffusion in the mass media and the public space, following advertising methods. Roudy, in the press release commenting on the results of the first phase of the campaign in May 1982, presented the campaign as 'an unprecedented event in the history of our country'. Indeed, even though the mid-1970s had seen the emergence of state campaigns in France - on road safety and alcohol/tobacco consumption - and even though symbolic action to transform opinion was characteristic of state feminism, the national campaign on contraception, following the same recipe, was still a novelty insofar as it did not aim to incite people to use contraception. ${ }^{34}$ The idea behind the campaign was to assert the right to decide whether to use contraception or not, which seemed to be obstructed by taboos and moral constraints.

\footnotetext{
${ }^{31}$ Assises of the national committee for the regulation of births on 1 October 1977 under the presidency of Prof Soutoul in the presence of Dr Lefebvre-Paul, technical adviser representing Mrs S. Veil, Minister of Health.

${ }^{32}$ Letter from Marie-Andrée Lagroua Weill-Hallé and J.-H. Soutoul to the Minister of Health, 7 April 1980.

33 On Yvette Roudy's public action, see Françoise Thébaud, 'Promouvoir les droits des femmes: ambitions, difficultés et résultats' [Promoting women's rights: ambitions, challenges and results] in Serge Berstein, Pierre Milza and J.-L. Bianco (eds), Les années Mitterrand: les années du changement (1981-1984) (Paris: Perrin, 2001), Jane Jenson and Mariette Sineau, Mitterrand et les Françaises, un rendez-vous manqué [Mitterrand and French Women: A Missed Appointment] (Paris: Presses de Sciences Po, 1995) and Anne Revillard, La cause des femmes dans l'État. Une comparaison France-Québec [The Cause of Women in the State. A Comparison between France and Quebec] (Grenoble: Presses Universitaires de Grenoble, 2016).

34 On the history of state communication in France, see 'L'État communicant', Quaderni, 33, 1997; on state feminist symbolic action, see Amy G. Mazur, Gender Bias and the State. Symbolic Reform at Work in the Fifth Republic France (Pittsburgh, PA: University of Pittsburgh Press, 1995) and Revillard, op. cit. (note 31).
} 
From 18 November to 9 December 1981, the state booked prime-time television spots, followed by messages on the radio, with the forceful slogan 'Today every woman must be able to choose'. At the same time, eight million leaflets indicating the addresses and opening hours of information and family planning centres in each region were distributed in post offices and town halls. In the second phase, radio advertisements were produced, consisting of sung dialogue between a man and a woman and the final message, 'Contraception can be talked about. In order to have a child when you wish to have one - in order to choose the contraceptive method best adapted to your situation - contact Contraception Information Centres or a Doctor.' At the same time, minimalist posters were put up in train stations and in the subway in Paris, which consisted only of the logo of the Ministry and the messages 'Today every woman must be able to choose' and 'In France, [there are] 1000 centres of information about contraception' as well as an address for additional information. In addition, advertising space was bought in several national, local and professional newspapers. The aim was to reach out to all social classes and to rural women as well as young people. For the same reason, the Ministry ordered a television fiction series, depicting a journalist enquiring about contraception and dealing with her own daughter's unwanted pregnancy. Designed as a persuasive tool, more likely to reach ordinary women, it was shown on Channel 3 (the most popular channel with the rural public) in the afternoon.

The campaign circumvented the interdiction against anti-natalist propaganda and publicity for contraceptives: methods were not mentioned on the posters nor in the television and radio spots. Yvette Roudy justified the campaign on the television news: 'Contraceptive methods are insufficient but above all they are not known or poorly known. And it is true that there is around the question an environment of fear and dramatisation. Therefore this campaign is made to tone down the existing atmosphere, to make it a subject anyone can talk about, peacefully.' She added, 'the campaign was made to indicate to everybody that information about contraception is a right'. This last statement indicates the will to assert the right to inform and to be informed. The presentation of the campaign by the newsreader conveyed the same idea: 'it's a campaign centred on a better understanding of contraception and not a campaign in favour of contraception itself; the aim is to inform, not to encourage' 35

However, the campaign was also meant to give information about contraceptive methods. The state produced one million brochures, 'giving the minimum information that must be known', to be distributed at conferences and forums. According to the presentation by the Ministry of Women's Rights, the brochure was meant to assert contraception as a fundamental right and to help women in particular and couples in general to 'better appropriate the chosen method in order to master the new right to own one's body'. ${ }^{36}$

This first national campaign was a change of paradigm regarding the role of the state as an information source about contraception. It was justified by the poor use of 'modern contraceptives' and the need to reduce abortions. The unequal access to information on contraception, dependent on social class and age group, was also an important argument. It was a clear statement of the right to be informed about contraception. Yvette Roudy deeply believed that contraception was a critical issue for women. However, she could not

\footnotetext{
${ }^{35}$ French Television Archives, INA (Audiovisual National Institute), Television News, 1pm, TF1 (Channel 1) 17 November 1981.

${ }^{36}$ French Family Planning Movement Archives, Contraception campaign, B 0153 CONT, Doc no 10440 and B 0131 CONT, Doc no 22544
} 
directly encourage contraception itself. Therefore, the campaign contributed to defining good practices regarding contraception. The television spot is revealing; it depicts women representing different social conditions in various situations justifying contraception: a country woman with three children ('one more would frankly be too much'); a young, not yet married working class couple; a young Parisian mother; three teenagers in high school wanting to learn about contraception; and a woman in her 30s saying she had her child when she wanted it and 'it was nice'. In other words, it was acceptable to use contraception after three children, to choose the right moment to have your children or to use it when you were too young. As a whole, the campaign contributed to individualising the contraception issue, showing individuals having to make choices. Women were placed at the centre, with the campaign clearly targeting them: it was led by the Ministry of Women's Rights and gave a lot of room for women's voices. The message asserted that contraceptive choice was a woman's choice; the brochure on contraceptive methods, for example, explained: 'It is up to each woman, at every moment of her life, to choose the method that suits her best. A discussion with her partner and with a doctor enables better adaptation to the chosen method.'

The campaign strongly affirmed that contraception was a public matter but also asserted the specific role of the state in the circulation of information about contraception, which resulted in criticism. The Ministry of Women's Rights opened a specific mailing address for the campaign and received hostile letters expressing moral, religious or medical arguments against contraception itself. Some expressed disagreement with the use of advertisement methods by the Ministry. The implication of the state in the matter of information about contraception was not well received in some quarters, as it contradicted religious observance and was considered an invasion of privacy. Some letters also offered critical views on the contraceptive methods presented by the campaign. ${ }^{37}$ Some feminist groups presented their approaches and demanded the widening of techniques presented in the brochure, while some men wrote about masculine contraception and others demanded more information about 'natural methods' (the only methods accepted by the Catholic Church). These reactions highlight the fact that the printing of a brochure by the Ministry of Women's Rights contributed to stabilising a list of recommendable methods, in a context where there was political consensus around them.

Some doctors also strongly regretted what they felt was the exclusion of physicians. The Doctors' Daily (Quotidien des médecins), a newspaper widely read by health professionals, organised a round table on the campaign and published a long report on 9 December 1982 issue under the title 'Contraception, the Physicians are There!' The editorial specified that physicians had been excluded twice in the campaign, during its elaboration and its unfolding, since 'it is not to them that the requests of contraception are sent'; it also reminded readers that the National Federation of French General Practitioners and the Confederation of French Medical Unions had protested against this 'manifest will to demedicalize contraception'. This reminds us that doctors had been the principal legitimate actors of information about contraception, which explains why some did not appreciate the state interfering in their relations with patients. However, even after the

${ }^{37}$ Summary of letters received by the Ministry: French National Archives, Ministry of Women's Rights, $19910616 / 24$. 
campaign, doctors, especially medical gynaecologists, remained central to the circulation of information on contraception, contributing to the shaping of patient practices. ${ }^{38}$

As a result, paradoxically, freedom of choice and the right to own one's body also became the duty to be informed. The campaign clearly defined information 'that should be known' and situations where birth control 'should be used'. This is a symptom of the emergence of a 'contraceptive norm' defined by Nathalie Bajos and Michèle Ferrand: 'the accessibility of medical contraceptive methods, [of] which efficiency is theoretically absolute, go[es] along with the rise of a new model establishing the birth of a child at the right moment as a positive aspiration' ${ }^{39}$ Women were expected to use birth control in certain situations, while unwanted pregnancies were considered unacceptable and abortion shameful. Women's right to control their bodies was also grounds for the state to assert women's responsibility regarding contraception and abortion practices. After 1982, it became more and more evident that every woman not only had the right to know but should know about contraception.

Even though the period between the 1950s and the 1980s was characterised by a major shift - the legalisation of contraception (1967) and abortion (1975) - the focus on information enables the highlighting of elements of continuity: the remaining interdiction against 'anti-conception propaganda' and advertisements for contraceptives - after selling and buying was made possible in the 1960s and 1970s - was a serious limitation of 'sexual liberation'. The power struggles around the definition of accurate information on contraception reveals the intense politicisation of the issue during the 1970s. Experts and activists produced their own information, while public policies on information were scarce. The lingering ban on anti-natalist propaganda, which lasted until the 1990s, established the notion that the French state should not encourage contraception by letting people know about it. The first national campaign in 1981-2 contributed to establishing contraception as a woman's right but also gave the message that women themselves were in charge of seeking the information.

\footnotetext{
38 Cécile Ventola, 'Prescrire un contraceptif: le rôle de l'institution médicale dans la construction de catégories sexuées' [Prescribing Contraception: The Role of Medicalisation in Gendering Birth Control], Genre, sexualité \& société, 12 (2014). http://journals.openedition.org/gss/3215.

${ }^{39}$ Nathalie Bajos and Michèle Ferrand, 'L'avortement à l'âge de raison' [Abortion in the Age of Reason], Mouvements, 17 (2001), 99-105, 102.
} 